\title{
Idiopathic Eosinophilic Cholecystitis with Cholelithiasis: A Report of Two Cases
}

\author{
Kolelitiyazisli İdiyopatik Eozinofilik Kolesistit: İki Olgu Sunumu
}

\author{
Monisha CHOUDHURY, Mukta PUJANI, Yogita KATIYAR, P. Lalita JYOTSNA, Archna RAUTELA
}

Department of Pathology, Lady Hardinge Medical College, NEW DELHI, INDIA

\begin{abstract}
Eosinophilic cholecystitis is a rare entity diagnosed on the basis of classical presentation of cholecystitis with presence of more than $90 \%$ eosinophilic infiltration within the gall bladder. The etiology of eosinophilic cholecystitis still remains obscure. However it is frequently associated with other more severe diseases like hypereosinophilic syndrome, eosinophilic-myalgia syndrome, parasitic infestations, few herbal medicines and certain drugs.

We report two cases who presented with gall stone disease, which on histopathological evaluation was diagnosed as eosinophilic cholecystitis. Retrospective analysis of their case histories and investigation did not reveal any known etiology. These cases are being reported because of their rarity and to highlight the importance of complete workup to rule out other associated disorders that may be a manifestation of a more severe disease.
\end{abstract}

Key Words: Eosinophilia, Cholecystitis, Cholelithiasis

\begin{abstract}
ÖZ
Eozinofilik kolesistit, safra kesesinde klasik kolesistit tablosu yanı sıra, \%90'nın üzerinde eozinofilik lökosit infiltrasyonu ile tanı konan nadir bir antitedir. Eozinofilik kolesistitin etiyolojisi hala açık değildir. Bununla birlikte hipereozinofilik sendrom, eozinofili-miyalji sendromu, parazitik enfestasyonlar, bitkisel tıp veya diğer bazı ilaçların kullanımı gibi daha ciddi hastalıklarla da sıklıkla ilişkilidir.

Safra kesesi taşı ile gelen ve histopatolojik inceleme ile eozinofilik kolesistit tanısı verilen iki olgu sunulmaktadır. Olguların özgeçmişlerinin retrospektif incelemesi ve klinik araştırmalar özel bir etiyoloji ortaya koymamıştır. Olgular, hastalığın nadir görülen bir antite olması ve ilişkili olabileceği daha ciddi hastalıkların dışlanabilmesi sürecindeki çalışmanın önemini ortaya koymak amaciyla sunulmuştur.
\end{abstract}

Anahtar Sözcükler: Eozinofili, Kolesistit, Kolelityazis

\section{INTRODUCTION}

Eosinophilic cholecystitis is a rare form of cholecystitis. It is diagnosed when transmural cellular infiltrate consists of more than $90 \%$ eosinophils. When the infiltrate consists of $50-75 \%$ eosinophils along with other inflammatory cells it is called lympho-eosinophilic cholecystitis (1).

\section{CASE REPORTS}

We report 2 cases of eosinophilic cholecystitis in two female patients aged 30 and 22 years.

\section{Case 1}

A 30-year-old female presented with colicky pain off and on for 2 years. Her investigations revealed hemoglobin $11 \mathrm{gm} / \mathrm{dl}$, total leucocyte count $4.5 \times 10^{3} / \mathrm{mm}^{3}$, differential leucocyte count neutrophils $55 / \mathrm{mm}^{3}$, lymphocyte $34 / \mathrm{mm}^{3}$, eosinophils $8 / \mathrm{mm}^{3}$, monocytes $3 / \mathrm{mm}^{3}$, platelets 1.9 lac/ $\mathrm{mm}^{3}$, absolute eosinophil count $350 / \mathrm{mm} 3$, blood sugar: $98 \mathrm{gm} / \mathrm{dl}$, alkaline phosphatase/ aspartate transaminase/

(Turk Patoloji Derg 2014, 30:142-144)

Received : 18.03.2011 Accepted : 25.12.2011 alanine transaminase 166/74/35 IU/ml, blood urea $23 \mathrm{mg} /$ $\mathrm{dl}$, serum creatinine $0.5 \mathrm{ng} / \mathrm{dl}$, and serum amylase $45 \mathrm{IU} /$ $\mathrm{ml}$.

Ultrasound was suggestive of chronic cholecystitis. A clinical diagnosis of chronic cholecystitis was made. On gross examination, the gall bladder was $6 \mathrm{~cm}$ in length with a wall thickness of $2 \mathrm{~mm}$. On opening, multiple mixed stones were present. Microscopically, in addition to chronic cholecystitis (Figure 1) there was a prominent eosinophilic infiltration (Figure 2) and a diagnosis of eosinophilic cholecystitis with cholelithiasis and focal pyloric metaplasia was reported.

Case 2

A 22-year-old female presented with pain in the right hypochondrium for the last 3 months. Her investigations revealed hemoglobin $10.6 \mathrm{gm} / \mathrm{dl}$, total leucocyte count $5.7 \times 10^{3} / \mathrm{mm}^{3}$, differential leucocyte count neutrophils $51 /$

Correspondence: Mukta PUJANI

Lady Hardinge Medical College, Department of Pathology,

NEW DELHI, INDIA

E-mail:drmuktapujani@gmail.com Phone: +09 313850205 
$\mathrm{mm}^{3}$, lymphocyte $33 / \mathrm{mm}^{3}$, eosinophils $10 / \mathrm{mm}^{3}$, monocyte $6 / \mathrm{mm}^{3}$, platelets $2.62 \mathrm{lac} / \mathrm{mm}^{3}$, absolute eosinophilic count $550 / \mathrm{mm}^{3}$, blood sugar: $105 \mathrm{gm} / \mathrm{dl}$, alkaline phosphatase/ aspartate transaminase/ alanine transaminase 203/136/63 $\mathrm{IU} / \mathrm{ml}$, blood urea $12 \mathrm{mg} / \mathrm{dl}$, serum creatinine $0.8 \mathrm{ng} / \mathrm{dl}$, and serum amylase $65 \mathrm{IU} / \mathrm{ml}$.

Sonography was suggestive of acute cholecystitis with cholelithiasis. A clinical diagnosis of a possible acute pancreatitis or acute cholecystitis was made. On gross examination, the gall bladder was $7.8 \mathrm{~cm}$ in length with a wall thickness of 1-2 $\mathrm{mm}$ and multiple mixed stones were also observed. Thus a histopathological diagnosis of eosinophilic cholecystitis with cholelithiasis was made.

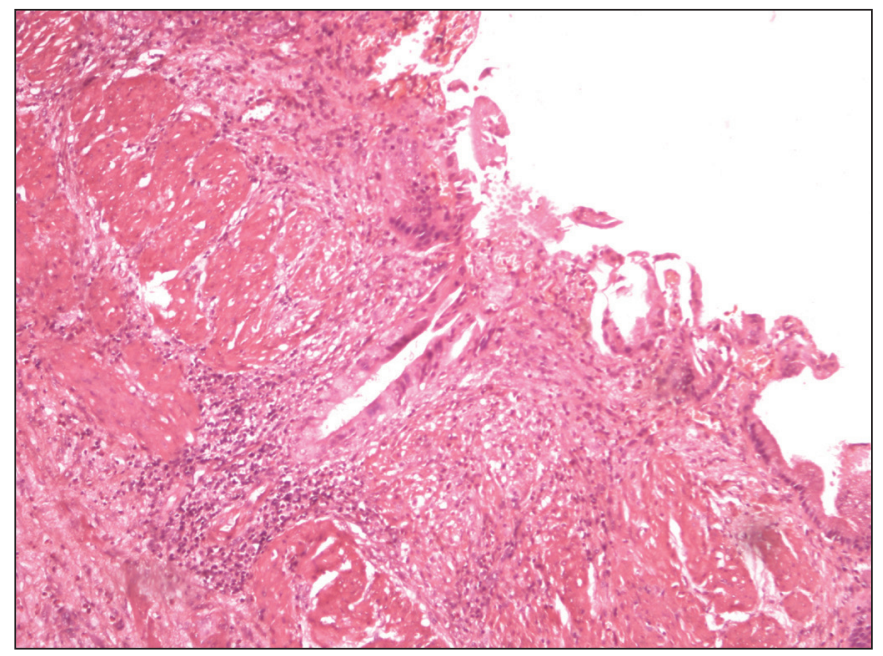

Figure 1: Gall bladder wall showing features of chronic cholecystitis (H\&E; x100).

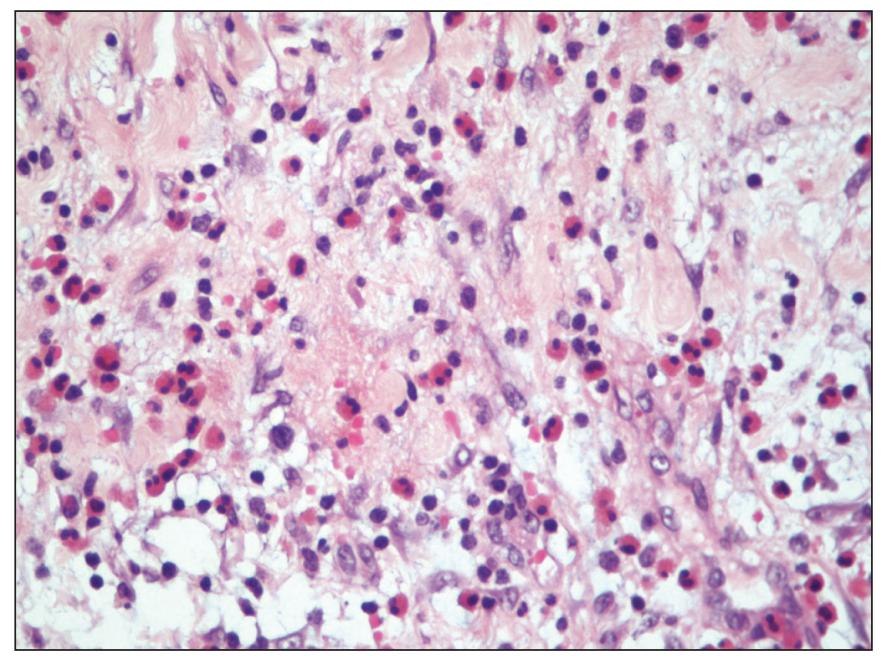

Figure 2: Gall bladder wall showing eosinophilic infiltration (H\&E; $\mathrm{x} 400)$.

\section{DISCUSSION}

Eosinophilic cholecystitis (EC) is a rare form of cholecystitis that was first described in 1949 (2). The prevalence of EC ranges from $0.25 \%$ to $6.4 \%$ as reported in various studies across the world $(1,3,4)$. EC is characterized by a dense transmural infiltration of eosinophils making up $90 \%$ or more of the leukocytic infiltration (3).

Dabbs et al. (1) reviewed 217 consecutive cholecystectomy specimens and found that a large number of eosinophils in the inflammatory infiltrate were three times more common in patients with acalculous cholelithiasis. In contrast, both of our patients had cholelithiasis.

Although there are quite few case reports describing EC $(5,6,7)$ the etiopathogenesis of disease still remains obscure. The proposed etiologies include local allergic reaction to substances released at the foci of inflammation, local diathesis involving gall stones, acalculous cholecystitis, parasites, hypereosinophilic syndrome (HES), eosinophilic gastroenteritis and eosinophilia myalgia (EM) syndrome. Certain drugs such as cephalosporins and herbal medicines have been implicated in EC $(5,6)$. A subset of idiopathic EC has also been reported, after excluding the above etiologies. However we did not find any possible etiology even after a thorough workup in both of our cases.

Histopathology remains the mainstay for diagnosis of eosinophilic cholecystitis as there is no specific clinical presentation. The treatment of choice for eosinophilic cholecystitis is cholecystectomy. However, steroids may be used as an adjuvant therapy if the disorder is associated with gastroenteritis (7).

The importance of reporting EC lies in the fact that it may be the presenting feature of many conditions such as HES and EM syndrome that are much more severe than cholecystitis itself. I cholecystitis is the only presenting complaint and a post-operative diagnosis of $\mathrm{EC}$ is made on histopathology, the patient must therefore be evaluated meticulously to rule out other associated diseases. Treatment may warrant more than a simple cholecystectomy if an underlying causative factor is discovered.

\section{REFERENCES}

1. Dabbs DJ. Eosinophilic and lymphoeosinophilic cholecystitis. Am J Surg Pathol. 1993;17:497-501.

2. Albot G, Poilleux, Olivier C, Libaude H, Cascarigny P. Les cholecystites a eosinophils. Presse Med. 1949;39:558-9.

3. Sanchez-Pobre P, Lopez-Rios MF, Colina F, Yela C, Manzano M, Rodriguez S, Martín A, Casís B, Garfia C, Castellano G, SolísHerruzo JA. Eosinophilic cholecystitis: An infrequent cause of cholecystectomy. Gastroenterol Hepatol. 1997;20:21-3. 
4. Mohan H, Punia RP, Dhawan SB, Ahal S, Sekhon MS. Morphological Spectrum of gall stone disease in 1100 cholecystectomies in North India. Indian J Surg. 2005;67:140-2.

5. Shakov R, Simoni G, Villacin A, Baddoura W. Eosinophilic Cholecystitis with a review of the literature. Ann Clin Lab Sci. 2007;37:182-5.

6. Singh DK, Shankar R, Gondal R, Malhotra V, Mishra P. Idiopathic eosinophilic cholecystitis with cholelithiasis: A case report and review of literature. Internet Journal of Surgery. 2008;16:2.

7. Punia RP, Arya S, Jain P, Bal A, Mohan H. Eosinophilic and Lympho-eosinophilic cholecystitis. Indian J Gastroenterol. 2003; 22:153-4. 